\title{
PENGARUH PENGGUNAAN ALAT PERAGA NUMBER MACHINE TERHADAP KEMAMPUAN PENALARAN MATEMATIS SISWA MADRASAH IBTIDAYYAH
}

\author{
Fery Muhamad Firdaus ${ }^{1)}$, Budi Prastya ${ }^{2)}$ \\ Program Studi Pendidikan Guru Madrasah Ibtidaiyah \\ UIN Syarif Hidayatullah Jakarta \\ fery.firdaus@,uinjkt.ac.id
}

Naskah diterima : 12 Februari 2018, direvisi : 28 Maret 2018, disetujui : 15 April 2018

\begin{abstract}
This study aims to determine the effect of the use of number machine props to the mathematical reasoning ability of students of grade IV MIN 2 of South Tangerang City on the matter of integers. The number machine tool is a semi-concrete tool or a function engine that performs mathematics on the task of operation. This research was conducted in class IV MIN 2 South Tangerang City. The method used in this research is quasi experimental method with the design of Nonequivalent Pretest-Posttest Control Group Design. The sample in this study consisted of 30 experimental stu-dents and control class which consisted of 29 students. The results showed that students taught by using number machine tools obtained the average value of students 'mathematical reasoning ability is higher than the average value of students' mathematical reasoning skills taught without using the number machine tool that is the significance value t_test $<0.05$. Based on result of calculation of influence test (effect size) obtained d value equal to 0,59 . The value of the effect size obtained interprets that the use of number machine tool has an influence in the medium category. Thus, this indicates that there is a moderate effect of using number machine props to the students' mathemat-ical reasoning abilities in Class IV MIN 2 South Tangerang City.
\end{abstract}

Keywords: Number Machine, Learning Integer, Mathematical reasoning ability.

Pengutipan: Fery Muhamad Firdaus \& Budi Prastya. (2018). Pengaruh Penggunaan Alat Peraga Number Machine terhadap Kemampuan Penalaran Matematis Siswa Madrasab Ibtidaiyah. JMIE: Journal of Madrasah Ibtidaiyah Education, 2(1), 2018, 29-42. jmie.v2i1.57. 


\section{PENDAHULUAN}

Rendahnya kemampuan matematis siswa SD/MI dalam memaknai matematika sudah dirasakan sebagai masalah yang cukup besar dalam pembelajaran matematika. Permasalahan ini muncul karena kebanyakan guru matematika sangat berkonsentrasi pada pencapaian hasil belajar atau mengejar skor nilai Ujian Akhir Sekolah Berstandar Nasional (UASBN) yang tinggi, sehingga penguasaan dan pemahaman matematika siswa rendah dan terabaikan.

Salah satu tujuan pembelajaran matematika adalah melatih cara berpikir dan bernalar dalam menarik kesimpulan, misalnya melalui kegiatan penyelidikan, eksplorasi, eksperimen, menunjukan kesamaan, perbedaan, konsisten, dan inkonsisten (Liberna dan Wiratomo, 2014). Karena dalam pembelajaran matematika siswa tidak hanya menghafal rumus dan latihan soal saja, melainkan siswa dapat menggunakan ilmu matematikanya untuk memecahkan permasalahan yang ada di sekitar kehidupan mereka. Pentingnya kemampuan penalaran matematis siswa berperan baik dalam dalam proses memahami matematika itu sendiri maupun dalam kehidupan sehari-hari. Pengembangan kemampuan penalaran matematis memerlukan strategi pembelajaran yang berkesan dan bermakna bagi siswa sehingga dapat mengakomodasi proses berpikir, proses bernalar, dan bersikap kritis.

Tujuan pembelajaran tersebut akan berhasil jika guru sebagai fasilitator dapat mengimplementasikan strategi pembelajaran yang relevan, berkesan, dan bermakna. Pembelajaran yang berkesan dan bermakna akan terbentuk jika dalam pembelajaran tersebut melibatkan siswa. Siswa lebih mudah menerima pelajaran jika mereka bersentuhan langsung dengan pembelajaran tersebut dalam bentuk konkret, karena pada dasarnya anak belajar melalui yang konkret. Konsep abstrak dalam pembelajaran akan lebih mudah dipahami siswa jika menggunakan media atau alat pembelajaran.

Selanjutnya konsep abstrak yang baru dipahaminya itu akan melekat dan bertahan lama jika siswa belajar melalui berbuat dan pengertian, bukan hanya melalui mengingatingat fakta. Oleh karena itu, dalam pembelajaran matematika idealnya menggunakan alat peraga, sebab dengan alat peraga: (1) mengkonkretkan suatu yang abstrak, (2) menyeragamkan penerimaan siswa atas materi pelajaran, (3) meningkatkan daya serap, (4) membantu menerangkan hal-hal yang sulit dipahami secara verbal (Hamzah dna Muhlisratini, 2014). Selain dari fungsi atau manfaat tersebut, penggunaan alat peraga dapat melatih kemampuan bernalar siswa sejak dini. Dengan begitu siswa dapat termotivasi dalam belajar, semakin semangat dan memiliki daya bernalar tinggi. 
Pelajaran matematika sangat perlu diberikan kepada semua siswa, karena hal ini berguna agar siswa dapat berpikir kritis, logis matematis, dan sistematis. Namun, pada umumnya saat siswa mendengar pelajaran matematika, mereka sudah merasa gelisah serta tidak percaya diri dan menyebabkan pelajaran matematika dipandang sebagai mata pelajaran yang sulit dipahami. Sikap tersebut tergambar dari raut wajah mereka ketika peneliti bertanya kepada seluruh siswa tentang matematika. Matematika juga dianggap sebagai masalah bagi kelulusan sebagian siswa. Masalah ini bermula dari kesulitan siswa dalam pembelajaran matematika karena pengetahuan diterima siswa secara pasif. Akibatnya, mayoritas siswa menganggap matematika sebagai pelajaran yang menakutkan sehingga siswa tidak termotivasi untuk belajar matematika dan siswa merasa terpaksa dalam mengikuti pelajaran matematika. Padahal, dalam kehidupan sehari-hari hampir setiap kegiatan menuntut untuk berpikir kritis, logis, matematis, dan sistematis. Jika ditelusuri salah satu penyebab permasalahan tersebut adalah cara mengajar guru yang tidak menggunakan alat peraga sehingga kurang menimbulkan motivasi belajar siswa dalam mengikuti pelajaran matematika dan mengakibatkan penalaran matematis siswa rendah.

Berdasarkan hasil observasi terhadap pembelajaran matematika pada operasi hitung bilangan bulat yang dilakukan di kelas IV MIN 2 Kota Tangerang Selatan, guru tidak menggunakan alat peraga yang relevan, selain itu guru kurang variatif dalam menggunakan model pembelajaran, guru kurang variatif dalam memberikan soal yang dapat melatih penalaran matematis siswa, rendahnya penalaran matematis siswa diketahui dari hasil latihan soal yang diberikan peneliti dalam bentuk uraian (essay). Dari 74 siswa kelas 4A (33 siswa) dan 4B (41 siswa) yang menjawab soal hanya 6 siswa yang mendapat nilai 60, yaitu 4 siswa kelas $4 \mathrm{~A}$ dan 2 siswa kelas $4 \mathrm{~B}$ atau sekitar 8,1\% siswa yang mencapai KKM (60). Selain itu pula terlihat siswa belum bisa memberikan penjelasan dengan model, fakta, sifat-sifat, dan hubungan pada saat diberikan soal cerita tentang bilangan bulat. Hal tersebut mengindikasikan bahwa kemampuan penalaran matematis siswa masih rendah.

Berdasarkan masalah-masalah tersebut, perlu adanya usaha untuk meningkatkan kemampuan penalaran matematis siswa. Peneliti memilih alat peraga number machine sebagai salah satu solusi untuk masalah-masalah dalam kemampuan penalaran matematis siswa khususnya pada tingkat sekolah dasar kelas IV dalam memahami konsep bilangan bulat. Number Machine adalah alat peraga semi konkret atau mesin fungsi yang pada matematika melakukan tugas operasi. Number Machine adalah alat peraga untuk permainan dalam matematika (Arsyad, 2014). Selain itu, Number Machine merupakan alat peraga semi konkret atau mesin yang pada matematika melakukan tugas 
operasi, alat ini berbentuk balok yang pada kedua ujungnya memiliki lubang. Lubang yang pertama sebagai tempat (input) memasukan angka dan lubang kedua sebagai tempat (output) mengeluarkan angka. Kegunaan number machine adalah sebagai permainan mesin yang dapat menjawab soal yang diberikan (Sundaya, 2014). Penggunaan alat peraga dalam pembelajaran matematika sangat penting, karena siswa pada sekolah tingkat dasar masih berpikir konkret sesuai dengan pendapat Piaget, yakni siswa sekolah dasar yang rata-rata berusia 7-12 tahun berada pada tahap operasional konkret. Selama tahap ini, siswa mengembangkan konsep dengan menggunakan benda-benda konkret untuk menjawab hal yang masih abstrak (Heruman, 2007).

Sebagai upaya menjawab permasalahan mengenai rendahnya kemampuan penalaran matematis siswa dan latar belakang masalah yang diuraikan diatas, maka peneliti terdorong untuk melakukan penelitian dengan judul "Pengaruh Penggunaan Alat Peraga Number Machine Terhadap Kemampuan Penalaran Matematis Siswa Kelas IV MIN 2 Kota Tangerang Selatan.”

\section{METODE PENELTTAN}

\section{Pendekatan Penelitian}

Pendekatan penelitian yang digunakan yaitu pendekatan kuantitatif, hal tersebut dikarenakan penelitian ini mengontrol bagaimana kelompok subjek penelitian diperlakukan dan kemudian mengukur bagaimana tindakan mempengaruhi setiap kelompok, sehingga diperlukan penelitian kuantitatif.

\section{Metode dan Desain Penelitian}

Metode yang digunakan dalam penelitian ini adalah eksperimen kuasi, hal ini dikarenakan penelitian dilaksanakan dengan maksud untuk mempelajari sesuatu dengan mengubah suatu kondisi dan mengamati pengaruhnya terhadap hal lain. Penelitian eksperimen kuasi yang akan dilaksanakan yaitu dengan bentuk nonequivalent groups pretestposttets design yang mengacu kepada pendapat Fraenkel dan Wallen (2007:278).

\section{Populasi dan Sampel}

Populasi dalam penelitian ini adalah seluruh siswa kelas IV MIN 2 Kota Tangsel. Sebagian dari jumlah populasi yang dipilih untuk sumber data disebut sampel. Teknik pengambilan sampel dilakukan dengan sampling purposive, yaitu teknik penentuan sampel dengan pertimbangan tertentu. Penentuan sampel dilakukan dengan memilih dua kelas yang memiliki kesamaan karakter, baik dari aspek kognitif, afektif, ataupun psikomotorik. Jumlah sampel di kelas eksperimen sebanyak 30 siswa, serta jumlah 
sampel di kelas kontrol sebanyak 29 siswa. Peneliti menentukan kelas yang terpilih sebagai kelompok eksperimen yang diajarkan dengan menggunakan alat peraga number machine, sedangkan kelas yang terpilih sebagai kelompok kontrol diajarkan dengan tidak menggunakan alat peraga number machine.

\section{Instrumen}

Instrumen yang digunakan pada penelitian ini berupa lembar tes kemampuan penalaran matematis siswa. Tes ini berupa tes subyektif dalam bentuk uraian. Instrumen terlebih dahulu diujicobakan sebelum digunakan untuk memperoleh data. Uji coba ini dimaksudkan untuk memperoleh validitas dan reliabilitas instrumen. Pengembangan instrumen dilakukan dengan cara pengujian validitas, pengujian reliabilitas, perhitungan daya pembeda dan perhitungan taraf kesukaran. Hasil pengujian validitas empiris dengan menggunakan rumus korelasi product moment dari pearson memperoleh hasil bahwa soal nomor 1,3,4, dan 5 memiliki tingkat signifikansi dengan kriteria sangat signifikan, sedangkan soal nomor 2 memiliki tingkat signifikansi dengan kriteria signifikan, sehingga semua soal dapat digunakan untuk mengukur penalaran matematis siswa. Hasil Perhitungan Reliabilitas yang Menggunakan Rumus Alpha-Cronbach menghasilkan sebesar 0,80, hal ini menunjukkan bahwa hasil uji coba instrumen memiliki reliabilitas yang tinggi.

\section{Analisis Data}

Analisis data hasil tes dimaksudkan untuk mengetahui pengaruh alat peraga number machine terhadap kemampuan penalaran matematis siswa Madrasah Ibtidaiyah. Teknik analisis data yang digunakan pada penelitian ini yaitu teknik statistik inferensial parameter, di mana teknik ini dilaksanakan dengan menggunakan uji t, taraf signifikansi 0,05. Selain itu, untuk mengetahui besar pengaruh, maka dilakukan uji effect size dari Cohen (Becker,2000).

\section{Prosedur Penelitian}

Penelitian dengan menggunakan metode quasi experimental design bentuk nonequivalent groups pretest-posttets design ini dilaksanakan dengan prosedur pelaksanaan penelitian sebagai berikut: Pertama, perencanaan dan persiapan penelitian, dimana pada proses ini dimulai dengan mendefinisikan masalah penelitian, mencari bahan rujukan, dan membuat hipotesis penelitian, menentukan desain penelitian, kemudian memilih sampel dari populasi tertentu sesuai dengan desain penelitian yang telah dipilih, serta membuat Rencana Pelaksanaan Pembelajaran (RPP), bahan ajar dan instrumeninstrumen yang digunakan ketika penelitian. Kedua, pelaksanaan penelitian, di mana pelaksanaan penelitian ini dilakukan dengan penempatan sampel pada kelompok 
eksperimen dan kelompok kontrol, memberi pretes masing-masing kelompok, didasarkan pada variabel dependent, mengatur kondisi perlakuan terhadap kelompok eksperimen bukan kepada kelompok kontrol, dan melakukan perlakuan atau treatment pelaksanaan pembelajaran menggunakan alat peraga number machine terhadap kelompok eksperimen, dan pembelajaran tidak menggunakan alat peraga number machine terhadap kelompok kontrol, serta masing-masing kelompok diberi posttes sesuai dengan variabel dependent. Ketiga, pengumpulan data dan analisis data yang telah diperoleh. Keempat, membuat laporan penelitian.

\section{HASIL PENELTIAN}

Pada penelitian ini, peneliti merancang dan mengembangkan sendiri alat peraga number machine. Alat peraga ini bermanfaat sebagai alat untuk anak-anak berlatih keterampilan berhitung, melatih penalaran, dan tentunya sambil bermain-main juga. number machine ini adalah sebuah kotak yang pada kedua ujungnya memiliki lubang. Lubang yang pertama sebagai tempat (input) memasukan sesuatu, misalnya sebuah angka 8 yang akan dioperasikan dan lubang yang satu lagi sebagai tempat keluar sesuatu yang telah dioperasikan. Adapun cara pembuatan alat peraga number machine adalah sebagai berikut:

1. Menyiapkan alat dan bahan, seperti: kayu, triplek, paku, palu, lem, penggaris, pensil, karton, bola plastik, cat kayu, dan spidol.

2. Membentuk kerangka number machine dengan kayu yang dilapisi triplek dan direkatkan dengan paku.

3. Buatlah 2 lubang untuk input dan output angka.

4. Berilah nomor pada bola plastik yang akan dijadikan alat input dan output.

5. Agar lebih menarik, berilah cat pada alat peraga number machine.

Berdasarkan pembuatan alat peraga tersebut, cara penggunaannya adalah jika kita memasukan angka 8 pada lubang input dan mengeluarkan angka 10, disinilah anak dilatih untuk bernalar, mengapa bisa keluar angka 10. Sebelumnya guru telah menyiapkan beberapa angka untuk dimasukan ke dalam number machine, misalnya guru memasukan angka 9, 10, dan 11. Jika guru akan memulai menggunakan number machine misalnya memasukan angka 8 maka akan mendorong angka yang ada di dalam number machine tersebut dan keluarlah angka 11. 
Selain menggunakan angka, number machine juga dapat menggunakan bola pingpong atau kelereng sebagai alat input dan output. Cara penggunaannya sama dengan menggunakan angka, yaitu kita masukan bola pingpong atau kelereng ke number machine, dengan soal tertentu maka banyaknya kelereng yang dimasukkan ke dalam number machine tersebut dengan proses yang diminta, maka hasilnya adalah jumlah kelereng yang keluar sesuai soal tersebut. Alat peraga number machine ini sangat cocok untuk digunakan sebagai media pembelajaran matematika di tingkat sekolah dasar, karena alat peraga ini unik, menarik, dan mudah sekali untuk digunakan. Alat peraga number machine yang sudah dibuat dan dikembangkan peneliti dapat dilihat pada gambar berikut ini.

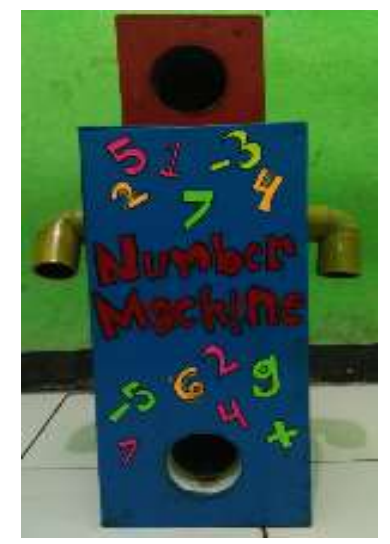

\section{Gambar 1 Alat Peraga Number Machine}

Alat peraga number machine dirancang untuk diujicobakan pengaruhnya terhadap penalaran matematis siswa Madrasah ibtidaiyah. Dimana peneliti menemukan rendahnya penalaran matematis siswa pada hasil pretes atau sebelum perlakuan penggunaan alat peraga number machine. Nilai rata-rata kelas 45,13. Nilai Median 46,15. Nilai modus 46. Nilai Minimum 15 dan Nilai maximum 62. Sedangkan hasil pretest pada kelas kontrol diperoleh data sebanyak 29 dengan jumlah data 1300 . Nilai rata-rata kelas 44,83. Nilai Median 46,15. Nilai modus 46. Nilai Minimum 38 dan Nilai maximum 54.

Selain rendahnya penalaran matematis, peneliti melihat efektifnya penggunaan alat peraga number machine terhadap penalaran matematis siwa yang sesuai dengan konsep abstrak matematika tersajikan dalam bentuk konkret berupa alat peraga number machine, lebih mudah untuk dipahami dan dimengerti serta dapat melatih penalaran matematis siswa. Alat peraga number machine relevan dengan karakteristik siswa pada masa operasional konkret karena hubungan antara konsep abstrak matematika dengan bendabenda di alam sekitar akan lebih dapat dipahami dengan jelas. Peneliti menggunakan alat peraga number machine untuk mengetahui pengaruhnya terhadap penalaran matematis 
siswa kelas 4 Madrasah Ibtidaiyah Negeri 2 Kota Tangerang Selatan. Berikut ini adalah foto-foto kegiatan pembelajaran dengan menggunakan alat peraga number machine.
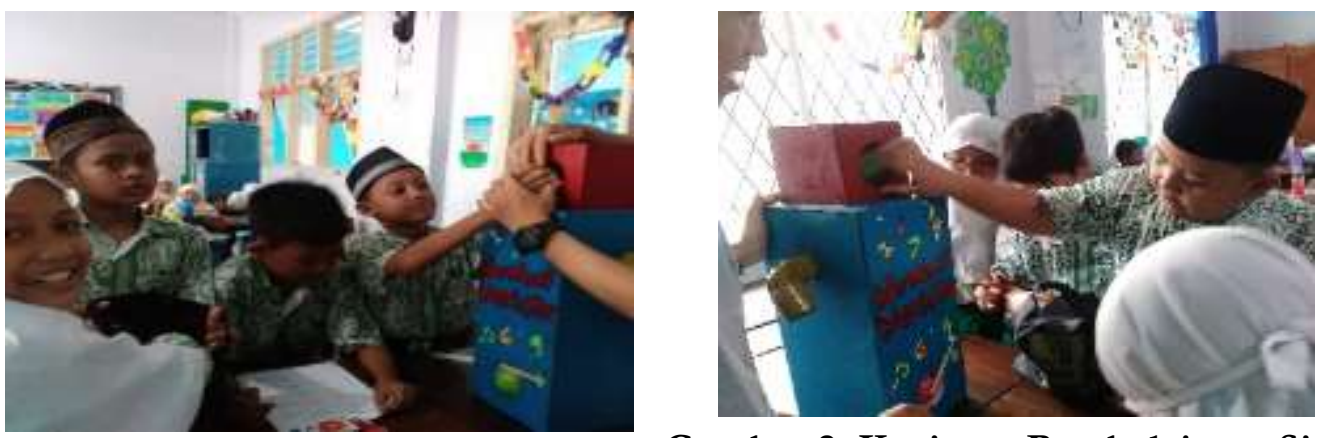

\section{Menggunakan Alat Peraga Number Machine}

Setelah dilaksanakannya treatment yaitu melaksanakan pembelajaran yang menggunakan alat peraga number machine di kelas eksperiman, dan pembelajaran yang tidak menggunakan alat peraga number machine di kelas kontrol, maka kegiatan penelitian selanjutnya yaitu mengadakan posttes. Hasil uji-t penalaran matematis pada saat pretes yaitu bahwa nilai signifikansi (P-value) untuk faktor pembelajaran sebesar $0,626 \geq 0,05$ maka $\mathrm{H}_{0}$ diterima. Dengan kata lain, tidak terdapat perbedaan rerata skor pretes penalaran matematis siswa antara kelompok kontrol dan kelompok eksperimen berdasarkan faktor pembelajaran. Akan tetapi, hasil uji perbedaan rerata posttes penalaran matematis siswa yaitu bahwa nilai signifikansi (P-value) untuk faktor pembelajaran sebesar $0,025<0,05$ maka $\mathrm{H}_{0}$ ditolak. Dengan kata lain, terdapat perbedaan rerata skor posttes penalaran matematis siswa antara kelompok kontrol dengan kelompok eksperimen.

Uji hipotesis posttest dengan menggunakan T-Test untuk mengetahui kemampuan awal antara kelas eksperimen yang menggunakan alat peraga number machine dan kelas kontrol tanpa menggunakan alat peraga number machine. Dalam uji data T-Test ini peneliti menggunakan program SPSS for windows yaitu independent Samples. Adapun kriteria pengujian hipotesis adalah jika signifikan T-Test $>0,05$ maka $H_{0}$ diterima dan $H_{1}$ ditolak. Sedangkan jika signifikan T-Test $<0,05$, maka $H_{0}$ ditolak dan $H_{1}$ diterima. 
Tabel 1.

Hasil Uji T-Test Posttest Kelas Eksperimen dan Kontrol

\begin{tabular}{ccccccc}
\hline Posttes & Mean & $\begin{array}{c}\text { Std. } \\
\text { Deviatiom }\end{array}$ & df & $\mathbf{t}_{\text {hitung }}$ & $\begin{array}{c}\text { Sih. (2- } \\
\text { tailed) }\end{array}$ & Kesimpulan \\
\hline Eksperimen & 77,44 & 10,866 & 57 & 2,297 & 0,025 & $\mathrm{H}_{0}$ ditolak \\
Kontrol & 71,35 & 9,398 & 56 & 2,302 & & \\
\hline
\end{tabular}

Dari Tabel 1 di atas, terlihat bahwa nilai posttest kelas eksperimen dan kelas kontrol signifikansi 0,025 . Maka $0,025<0,05$ artinya $H_{0}$ ditolak dan $H_{1}$ diterima maka dapat disimpulkan terdapat pengaruh yang signifikan antara hasil posttest kelas eksperimen dan kontrol. Data lengkap terdapat pada lampiran 22. Setelah melakukan uji t, pengujian selanjutnya yaitu uji pengaruh. Uji pengaruh ini dilakukan untuk mengetahui seberapa besar pengaruh yang didapatkan dari penggunaan alat peraga number machine terhadap penalaran matematis siswa pada pokok bahasan bilangan bulat. Hasil perhitungan effect size diinterpretasikan dengan menggunakan klasifikasi menurut Cohen (Becker,2000). Hasil perhitungan effect size pada penelitian ini yaitu dengan menggunakan bantuan program Effect Size (Cohen's d) Calculator For a Students t-Test oleh Daniel Soper, diperoleh nilai sebesar 0.59. Data lengkap terdapat pada lampiran 23. Nilai effect size ini termasuk dalam tingkatan pengaruh yang sedang. Sehingga dapat disimpulkan bahwa penggunaan alat peraga number machine memberikan pengaruh yang positif terhadap kemampuan penalaran matematis siswa di kelas IV Madrasah Ibtidaiyah Negeri 2 Kota Tangerang Selatan pada bahasan operasi hitung bilangan bulat.

\section{DISKUSI}

Berdasarkan penelitian yang telah dilakukan didapatkan bahwa terdapat pengaruh yang signifikan pada penggunaan alat peraga number machine terhadap penalaran matematis siswa kelas 4 Madrasah Ibtidaiyah Negeri 2 Kota Tangerang Selatan. Hal ini dapat dilihat dari nilai rata-rata kelas eksperimen (posttest) sebesar 77,44 dan kelas kontrol (posttest) sebesar 71,35. Perbedaan hasil penalaran yang terjadi antara kedua kelas yaitu kelas eksperimen dan kontrol karena perlakuan yang berbeda, yakni pada kelas eksperimen menggunakan alat peraga number machine dalam proses pembelajarannya sedangkan kelas control yang tidak menggunakan alat peraga number machine. 
Data di atas senada dengan pendapat Gardner, et all., (Lestari dan Yudhanegara, 2015) yang mengungkapkan, bahwa penalaran matematis adalah kemampuan menganalisis, menggeneralisasi, mensintesis/mengintegrasikan, memberikan kontrol yang tepat dan menyelesaikan masalah tidak rutin. Indikator kemampuan penalaran matematis menurut Hendriana dan Soemarmo (2014), yaitu:

1. Menarik kesimpulan logis.

2. Memberikan penjelasan dengan model, fakta, sifat-sifat, dan hubungan.

3. Memperkirakan jawaban dan proses solusi.

4. Menggunakan pola dan hubungan untuk menganalisis situasi atau membuat analogi dan generalisasi.

Hal tersebut telah dibuktikan dengan pengujian hipotesis dengan program SPSS 22 yang menyatakan bahwa $t_{\text {hitung }}$ berada di daerah penerimaan $H_{1}$ yaitu $t_{\text {hitung }}<0,05$ (taraf signifikansi) atau 0,002<0,005 yang berarti $H_{0}$ ditolak dan $H_{1}$ diterima, hal dikarenakan hasil t-hitung kuang dari taraf signifikansi. Sehingga dapat disimpulkan bahwa pembelajaran dengan menggunakan alat peraga number machine berpengaruh positif terhadap penalaran matematis siswa kelas 4 Madrasah Ibtidaiyah Negeri 2 Kota Tangerang Selatan.

Senada dengan teori dan indikator yang diungkapkan Gardner, et all., terkait pembuktian terhadap penalaran, NCTM (National Council Of Teachers Of Mathematics) pada tahun 2000 menegaskan bahwa bukti matematika adalah cara formal mengungkapkan jenis tertentu penalaran dan pembenaran. "Mathematical reasoning and proof offer powerful ways of developing and expressing insights about a wide range of phenomena. People who reason and think analytically tend to note patterns, structure, or regularities in both real-world situations and symbolic objects; they ask if those patterns are accidental or if they occur for a reason; and they conjecture and prove. Ultimately, a mathematical proof is a formal way of expressing particular kinds of reasoning and justification". Teori tersebut sesuai dengan pembuktian yang dilakukan siswa dalam memecahkan masalah pada soal atau lembar kerja siswa yang telah mereka kerjakan.

Pada pelaksanaan pembelajaran di kelas eksperimen, di mana peneliti menggunakan alat peraga number machine suasana pembelajaran sangat menyenangkan, karena siswa sangat tertarik dan antusias untuk belajar matematika dengan menggunakan alat peraga number machine. Diawali dengan demontrasi peneliti dalam menggunakan alat peraga tersebut kemudian siswa mengamati dan masing-masing kelompok mencoba mempelajari matematika khususnya materi bilangan bulat dengan alat peraga number machine. Alat peraga tersebut sangat membantu melatih penalaran matematis siswa. 
Penggunaan alat peraga number machine efektif jika diterapkan di sekolah dasar, hal ini senada dengan hasil penelitian Oktavianingtyas (2015) yang membuktikan bahwa Karakteristik siswa Sekolah Dasar yang menonjol adalah senang bermain, selalu bergerak, bekerja atau bermain dalam kelompok, dan senantiasa ingin melaksanakan dan merasakan sendiri (langsung praktek). Karakter-karakter ini memaksa guru untuk lebih kreatif dalam menentukan strategi pembelajaran agar pembelajaran berjalan lebih efektif dan menyenangkan. Media atau alat peraga yang menarik mampu menjadi salah satu solusi untuk meningkatkan aktivitas guru dan siswa dalam pembelajaran operasi hitung dasar bilangan bulat. Peningkatan ini berakibat pula pada meningkatnya hasil belajar siswa sekolah dasar. Tentukan hasil penelitian tersebut mendukung hasil penelitian ini bahwa penggunaan alat peraga number machine berpengaruh terhadap penalaran siswa sekolah dasar.

Hasil penelitian lain yang menggunakan media atau alat peraga dalam pembelajaran bilangan bulat di sekolah dasar yaitu Setyaningsih dan Mudjiarti (2014) yang membuktikan penggunaan media mistar bilangan dapat meningkatkan hasil belajar siswa sekolah dasar pada konsep pengurangan dan penjumlahan bilangan bulat. Oleh karena itu, alat peraga dan media pembelajaran sangatlah diperlukan dalam memingkatkan kemampuan siswa dalam berbagai konsep, salah satunya konsep pengurangan dan penjumlahan bilangan bulat. Sehinggan alat peraga number machine dapat menjadi alternative dalam pembelajaran bilangan bulat di sekolah dasar.

Penggunaan alat peraga number machine juga dapat meningkatkan motivasi belajar siswa. Hal ini senada dengan hasil penelitian Endarwati dan Widjajanti (2016) yang menunjukkan bahwa peningkatan motivasi belajar siswa disebabkan karena siswa dapat berinteraksi secara langsung, mencoba melakukan operasi hitung bilangan bulat dan jika salah dapat mengulangnya sampai benar sekaligus mendapatkan umpan balik. Hal tersebut menyebabkan siswa lebih bersemangat, ulet menghadapi kesulitan dan tidak mudah menyerah sehingga mereka tidak lagi mengeluh saat mendapatkan tugas dari guru. Beberapa hal tersebut merupakan tanda-tanda siswa yang termotivasi dalam belajar. Sehingga penggunaan alat peraga dan media seperti alat peraga number machine dapat meningkatkan motivasi belajar siswa dalam pembelajaran bilangan bulat di sekolah dasar.

Berdasarkan data tersebut, maka dapat disimpulkan bahwa terdapat pengaruh pada penggunaan alat peraga number machine terhadap penalaran matematis siswa kelas 4 Madrasah Ibtidaiyah Negeri 2 Kota Tangerang Selatan. Dalam pelaksanan penelitian penulis menyadari bahwa penelitian ini terdapat beberapa hal yang belum sempurna. 
Berbagai upaya telah dilakukan dalam pelaksanaan penelitian ini agar mendapat hasil yang maksimal. Namun, masih terdapat beberapa faktor yang sulit dikendalikan sehingga membuat penelitian ini mempunyai beberapa keterbatasan sebagai berikut:

1. Fokus bahasan matematika dengan menggunakan alat peraga number machine pada penelitian ini adalah operasi hitung bilangan bulat.

2. Terbatasnya alat peraga numbere machine yang disediakan dalam penelitian sehingga siswa berkumpul secara kelompok dan menggunakan alat peraga tersebut secara bergiliran.

3. Kontrol terhadap subjek penelitian hanya meliputi alat numbere machine, materi operasi bilangan bulat, dan penalaran matematis siswa. Variable lain tidak terkontrol, karena penelitian dapat saja dipengaruhi oleh variabel lain di luar variabel yang telah ditetapkan dalam penelitian ini.

\section{KESIMPULAN}

Hasil penelitian ini menunjukkan bahwa terdapat pengaruh penggunaan alat peraga number machine terhadap penalaran matematis siswa di kelas IV MIN 2 Kota Tangerang Selatan. Hal ini dapat dilihat dari nilai rata-rata hasil posttest kelas eksperimen sebesar 77,44 dan kelas kontrol sebesar 71,35. Selain itu, berdasarkan pengujian hipotesis dengan program SPSS 22 yang menyatakan bahwa $t_{\text {hitung }}$ berada di daerah penerimaan $H_{1}$ yaitu $t_{\text {hitung }}<0,05$ (taraf signifikansi) atau 0,002 $<0,005$ yang berarti $H_{0}$ ditolak dan $H_{1}$ diterima. Berdasarkan uji pengaruh diperoleh nilai sebesar 0.59 yang menunjukkan bahwa termasuk ke dalam kategori sedang. Sehingga dapat disimpulkan bahwa terdapat pengaruh pada penggunaan alat peraga number machine terhadap penalaran matematis siswa kelas 4 Madrasah Ibtidaiyah Negeri 2 Kota Tangerang Selatan.

Implikasi penelitian ini ialah terdapat pengaruh penggunaan alat peraga number machine terhadap kemampuan penalaran matematis siswa implikasi penelitian ini terbagi menjadi 2 bagian yakni implikasi teoritis dan praktis. Implikasi teoritis dapat dipaparkan sebagai berikut: Penggunaan alat peraga number machine dapat memengaruhi kemampuan penalaran matematis siswa jika diterapkan pada pembelajaran matematika tingkat sekolah dasar. Hal ini senada dengan teori Brunner, yakni belajar matematika akan lebih berhasil jika proses pengajaran diarahkan kepada konsep-konsep dan struktur yang termuat dalam pokok bahasan yang diajarkan dan dengan menggunakan alat peraga serta 
diperlukannya keaktifan siswa tersebut. Oleh karena itu, alat peraga ini cocok diterapkan pada proses belajar mengajar

Adapun implikasi praktis dari penelitian ini dapat dijelaskan sebagai berikut: Penggunaan alat peraga number machine dapat memengaruhi kemampuan penalaran matematis siswa di kelas IV MIN 2 Kota Tangsel pada materi operasi hitung bilangan bulat. Penggunaan alat peraga ini mempunyai implikasi yang memudahkan guru dalam melibatkan siswa untuk mencapai tujuan pembelajaran dan mempengaruhi penalaran matematis siswa.

\section{DAFTAR PUSTAKA}

Arsyad, A. (2014) Media Pembelajaran. Jakarta: PT Rajagrafindo Persada.

Becker, L. (2000). Effect Size (ES). [Online]. Tersedia: http://www. bwgriffin.com/gsu/courses/edur9131/content/EffectSizeBecker.pdf. Januari 2017]

Endarwati, E. D. dan Widjajanti, D. B.(2016). Peningkatan Motivasi Dan Prestasi Belajar Operasi Hitung Bilangan Bulat Siswa Kelas 4 Melalui Media Visual Interaktif. Jurnal Penelitian Ilmu Pendidikan, Vol 9, No 1, hal 53-69.

Fraenkel, J. R. dan Wallen, N. E. (2007). How to Design and Evaluate Research in Education. New York: Mcgraw hill.

Hamzah, H.M. Ali dan Muhlisrarini. (2014). Perencanaan dan Strategi Pembelajaran Matematike. Jakarta: PT Grafindo Persada.

Hendriana dan Soemarmo. (2014). Penilaian Pembelajaran Matematika. Bandung: PT Refika Aditama.

Heruman. (2007). Model Pembelajaran Matematika di Sekolah Dasar. Bandung: PT. Remaja Rosdakarya.

Lestari, K. E. dan Yudhanegara, M. R. (2015). Penelitian Pendidikan Matematika. Bandung: PT Refika Aditama.

Liberna, H. dan Wiratomo, Y. (2014) Metode Pembelajaran Matematika. Jakarta: Mitra Abadi.

NCTM. (2000). Principles and standards for school mathematics. Reston: Virginia. 
Oktavianingtyas, E. (2015). Media Untuk Mengefektifkan Pembelajaran Operasi Hitung Dasar Matematika Siswa Jenjang Pendidikan Dasar. Jurnal Pancaran, Vol. 4, No. 4, hal 207-218.

Setyaningsih, A. N. dan Mudjiarti, T. (2014). Penggunaan Media Mistar Bilangan Untuk Meningkatkan Hasil Belajar Penjumlahan Bilangan Bulat Siswa Sekolab Dasar. Jurnal Pendidikan Guru Sekolah Dasar. Vol 2. No 2. Hal 1-14.

Sundaya, R. (2014) Media dan Alat Peraga dalam Pembelajaran Matematika, Bandung: Alfabeta. 